\title{
A MISTAGOGIA COMO PALAVRA E GESTOS NA OBRA DE SÃO CIRILO DE JERUSALÉM: O ATO DE CONSTRUIR O IMAGINÁRIO RELIGIOSO ${ }^{1}$
}

Prof. Ms. Pe. João Mendonça*

\begin{abstract}
RESUMO
O autor ousou apresentar a teologia de São Cirilo a partir dos conceitos da comunicação. Mostrou que São Cirilo de Jerusalém criou um estilo simbólico e gestual de criar o conteúdo da Palavra de Deus a partir do espaço sagrado e, simultaneamente, possibilitou aos seus ouvintes o sonho do imaginário religioso como mapa da realidade a ser seguido. Assim, logrou ressignificar a comunicação como mistagogia, que quer dizer conduzir o interlocutor a uma "virtualização do corpo" como experiência de uma linguagem que, mais do que texto, produz um estilo de vida que refaz o aprendizado segundo o tempo e os espaços possíveis, mergulhado no Mistério de Deus.
\end{abstract}

\begin{abstract}
The author dared to present the theology of St. Cyril from the concepts of communication. Showed that St. Cyril of Jerusalem created a style and symbolic gestures create the content of the Word of God from the sacred space and simultaneously, enabled his listeners to dream of religious imagery as a map of reality to be followed. Thus, re-managed communication as mystagogy mean that, say, to lead the recipient to a "virtualization of the body" experience as a language rather than text, produces a lifestyle that remakes the second time and learning possible spaces, steeped in the mystery of God.
\end{abstract}

1 O presente artigo é um extrato da monografia apresentada pelo autor para especialização no curso de cultura e meios de comunicação: uma abordagem teórico-prática em 2010 a PUC/SP e Sepac/SP.

* Presbítero salesiano, bacharel em Teologia pela Pontifícia Universidade Xaveriana de Bogotá-Colômbia. Mestre em Educação com especialização em Pedagogia para a formação religiosa e presbiteral, pela Pontifícia Universidade Salesiana de Roma/Itália. Pós-graduado em Educação Sexual pela Unisal/SP e em Comunicação pelo Sepac e PUC/SP. 
Palavras-chave: mistagogia, imaginário religioso, palavra, comunicação, Padres da Igreja.
Keywords: mystagogy, religious imagery, word, communication, Church Fathers.

\section{INTRODUÇÃO: VIDA E QUESTÕES TEOLÓGICAS DE CIRILO DE JERUSALÉM}

Cirilo de Jerusalém foi um cristão do IV século. Provavelmente nasceu em Jerusalém no ano 315. Sua vida pode ser definida em duas dimensões ao longo de 77 anos (faleceu em 387): o grande empenho pastoral como bispo-mistagogo, ${ }^{2}$ e o envolvimento, mesmo contra a sua vontade, nas disputas teológicas que sacudiram a Igreja Católica no Oriente. ${ }^{3}$ A formação de Cirilo se concentrou no campo das Letras e da Bíblia.

Os séculos IV e V foram marcados por grandes heresias ou disputas teológicas. Uma delas foi a questão Trinitária, quando teólogos cristãos negaram a divindade de Jesus Cristo e também do Espírito Santo. ${ }^{4}$ Uma corrente forte do pensamento teológico floriu nesta época formando assim "o ciclo de ouro da patrística" entre o Concílio de Niceia e o de Calcedônia (325-451), no qual o batismo de adultos e a formulação do Credo (Ato de Fé) foram fortemente defendidos. ${ }^{5}$

No ano de 345, Cirilo foi ordenado presbítero por Máximo II, a quem sucedeu apoiado pelos eusebianos. ${ }^{6}$ Em 348, Acácio, o grande metropolita de Cesareia da Palestina, ordenou Cirilo Bispo. Contudo, logo depois, devido a algumas intrigas doutrinais, o mesmo Acácio tornou-se inimigo de Cirilo, e o enfrentou em tremendas disputas jurisdicionais, porque Cirilo reivindicava a autonomia de sua sede episcopal em relação a Acácio. Contudo, Acácio compactuava

2 A mistagogia é um método de instrução que introduz o ouvinte no mistério que se quer revelar. Mista significa "mistério" e gogia quer dizer "guiar, conduzir". O mistagogo é aquele que conduz o ouvinte para o mistério. Cf. CALOGERO, R. Lo sfondo esegetico della catechesi palestinense in Epifanio di Salamina e in Cirillo di Gerusalemme, pp. 121-129.

3 BENTO XVI. São Cirilo de Jerusalém. Audiência geral, n. 26, p. 12.

4 MONDONI, D. História da Igreja na Antiguidade, p. 121; SEMONETTI, M. La crisi ariana nel IV século, p. 28.

5 ELORRIAGA, C. San Cirilo de Jerusalém. Catequesis, pp. 28-50.

6 Os eusebianos eram assim chamados por seguirem a doutrina do grande Eusébio de Cesareia, considerado o "pai da história da Igreja". Nasceu em 265 e faleceu em 339. A obra teológica de Eusébio é composta de escritos apologéticos, exegese bíblica e história da Igreja. 
com Ário (260-325), ${ }^{7}$ nascido na Líbia, e que mais tarde exerceu o ministério presbiteral na Igreja de Alexandria. Ário negou a divindade de Jesus Cristo. ${ }^{8}$ Ensinava que Jesus era apenas uma criatura e não tinha a mesma essência de Deus porque o único não gerado, não criado, sem princípio é o Pai. ${ }^{9}$

As consequências para Cirilo destes conflitos foram três exílios no espaço de vinte anos: O primeiro em 357 por mandato do Sínodo de Jerusalém, mas em seguida foi anistiado pelo Concílio de Selêucia em 358. O segundo exílio foi em 360 por obra de Acácio. O Imperador Constâncio o mandou, preso, de volta ao exílio. Permaneceu até 362, quando foi novamente anistiado por Juliano. O mais longo exílio foi o terceiro, de 367 a 378, por iniciativa do Imperador Filoariano Valente. Quando Filoariano morreu, Cirilo retornou a sua sede. Alguns anos depois, em 381, totalmente restabelecido, Cirilo participou ativamente do $1^{\circ}$ Concílio de Constantinopla, no qual os bispos reconheceram seus méritos e sua doutrina.

Cirilo é considerado catequista e também teólogo. ${ }^{10}$ No entanto, sua obra não se equipara a de outros padres do século IV como Santo Atanásio, Santo Hilário e São Basílio e todos os demais padres capadócios. Contudo, o testemunho de fé e de segura interpretação da Tradição antiga fez eco na vida de Cirilo e nas suas catequeses, sobretudo na convergente doutrina do $1^{\circ}$ Concílio de Niceia de 325 , convocado pelo Imperador Constantino, que discutiu a doutrina cristológica. 270 bispos representantes do Egito, Palestina, Síria, Fenícia, Ásia Menor, Itália, Grécia e Espanha se posicionaram contra a doutrina de Ário e criaram a fórmula "O Filho é gerado da essência do Pai".11 Os padres de Niceia usaram o termo grego homoousía ("consubstancial"). A questão, contudo, não ficou resolvida apenas com o Concílio, pois o conflito durou de 318 a 381 , quase toda a vida de Cirilo.

\section{OBRAS DE CIRILO DE JERUSALÉM}

Por volta do ano 350, Cirilo, bispo de Jerusalém, desenvolveu 23 catequeses que marcaram profundamente a história do cristianismo primitivo.

\footnotetext{
HAMMAN, A. Os padres da Igreja, p. 180.

SEMONETTI, M. La crisi ariana nel IV século, p. 28.

9 Ibid., p. 47; MONDONI, D. História da Igreja na Antiguidade, p. 122.

10 ElORRIAGA, C. San Cirilo de Jerusalém. Catequesis, p. 32.

11 SEMONETTI, M. La crisi ariana nel IV século, pp. 78-88.
} 
As 18 primeiras tinham como objetivo preparar o catecúmeno para o batismo. Todas elas realizadas na Basílica do Santo Sepulcro. As primeiras (1-5) delineavam as disposições para ser batizado: conversão dos costumes pagãos, o sentido do batismo, as dez verdades contidas no Credo. As catequeses seguintes (6-18) eram contra a ideologia ariana. As cinco últimas (19-23) foram chamadas de "mistagógicas" porque se referiam ao sacramento do batismo recebido na noite de Páscoa e se realizam durante o Tempo Pascal. Eram assim organizadas: as duas primeiras (19-20) são comentários sobre o batismo. As sucessivas se debruçam sobre os temas da crisma, do Corpo e Sangue de Cristo, da liturgia Eucarística e do Pai-Nosso.

Trata-se, pois, de uma obra sinfônica entre o Antigo e o Novo Testamento. O conteúdo moral se unifica entre Doutrina e Mistagogia. Enquanto doutrina, transforma a vida do catecúmeno a partir de dentro na vida nova em Cristo. A mistagogia era o mergulho no mistério celebrado na noite de Páscoa através dos ritos (imersão na água), com sinal de morte e gestos que iluminavam a vida do fiel na graça batismal. Existia um efeito visual e psicológico de grande força na mente dos neófitos a tal ponto que eles passavam a agir imbuídos de uma nova experiência de vida, agora em Jesus Cristo.

Segundo Baronto, ${ }^{12}$ existe um eixo comum na metodologia de Cirilo: Há uma experiência ritual que corresponde a um período propedêutico no qual o neófito passa a compreender com toda a simbologia presente nos ritos o significado do batismo. O passo seguinte é a catequese, pregação, que, somada ao rito, contribui para uma melhor compreensão da Vigília celebrada na noite de Páscoa, na qual o fiel recebe o batismo. O terceiro nível é a compreensão dos gestos e do rito depois de passar por todos eles. $O$ neófito guarda na memória todos os ensinamentos recebidos e passa a agir movido pela realidade nova de vida. É obvio que dentro de leitura imagética temos aqui uma arte criativa de comunicação da mensagem que toca de fato a vida da pessoa em profundidade. Não apenas uma explicação, mas ritualidade; não mero rito, mas pregação; não uma pregação sem gestos, mas visibilidade e audição.

12 BARONTO, L. E. A metodologia litúrgico-catequética, p. 54. Ver também o esquema apresentado por LELO, F. Catequese com estilo catecumenal, pp. 24-26. 


\section{CONTEÚDO DAS CATEQUESES}

É importante destacar os elementos essenciais das catequeses para compreendermos o conjunto das argumentações que serão desenvolvidas a seguir.

Cirilo desenvolvia, com os catecúmenos, elementos essenciais do Credo apostólico, a partir de sua sensibilidade. Não é possível afirmar ou negar que o texto que transcrevo em seguida é totalmente fiel aos ensinamentos de Cirilo, embora represente sua essencialidade:

Cremos em um Deus, Pai todo-poderoso, Criador do céu e da terra, de todas as coisas visíveis e invisíveis. E em um Salvador Jesus Cristo, Filho Unigênito de Deus, gerado do Pai, Deus verdadeiro, Antes de todos os séculos, pelo qual foram feitas todas as coisas. Que veio na carne e se fez homem (da Virgem e do Espírito santo). Foi crucificado e sepultado. Ressuscitou ao terceiro dia. E subiu aos Céus e está sentado à direita do Pai. E virá na glória para julgar os vivos e os mortos, cujo reino não terá fim. E em um Espírito Santo, o Paráclito que falou nos profetas. E em um batismo de penitência para remissão dos pecados. E em uma santa católica Igreja. E na ressurreição da carne. E na vida eterna. ${ }^{13}$

Nas catequeses mistagógicas, Cirilo não discute questões dogmáticas. Sua intenção é ajudar o fiel a experimentar o ato de fé e a compreendê-lo. Por isso, este Credo não é encontrado integralmente nas catequeses. Ele insistia com os catecúmenos em que o valor estava em saber guardar os segredos recebidos, gravando-os na memória. Era na vida cotidiana que o fiel deveria manifestar o sentido das palavras. $O$ texto na verdade é uma compilação feita por taquígrafos. É um resumo das palavras de Cirilo nas catequeses. Contudo, apesar de todas as limitações que uma transcrição pode ter, o texto nos remete aos elementos substanciais do Credo que ele ensinava.

A partir do texto transcrito, é possível reconhecer as fontes da fé que ele ensinava: a Sagrada Escritura, a Tradição cristã, o sentido da Trindade e sua unidade na consubstancialidade das três pessoas divinas, o sentido

13 SÃO CIRILO DE JERUSALÉM. Catequeses mistagógicas, p. 19. 
da Redenção, os Sacramentos etc. Somente assim podemos perceber como ele combatia o arianismo e colocava em prática os ensinamentos do Concílio de Niceia: Jesus é verdadeiramente Deus e o Espírito Santo, mesmo sendo distinto do Pai e do Filho, goza da mesma divindade. No entanto, Cirilo apresenta não um tratado sobre temas doutrinais mas sim uma explicação do Símbolo Apostólico. Nisto ele foi genial, porque soube superar o espírito apologético - defesa da fé - e gerou um sistema mistagógico capaz de converter o catecúmeno e prepará-lo para o testemunho de uma fé coerente com a Tradição da Igreja.

A compreensão que ele tem do batismo é clara e direta. No batismo, o cristão assume uma nova realidade e é revestido de Cristo: "Nós nos tornamos uma coisa só com ele por uma morte semelhante à sua" $(R m 6,5)$, embora seja na catequese sobre a crisma que ele ensinará que a unção com o óleo transforma o cristão num companheiro inseparável de Jesus Cristo que, por sua vez, alimenta a vida do fiel na Eucaristia. Inclusive ele usa o termo "consanguíneo com Cristo" para dizer que se trata de algo visível aos olhos que fortalece a alma. O cristão se torna o que recebe.

Com toda esta lógica de ressignificação da vida, as catequeses de Cirilo se transformaram também em teologia porque traziam na sua raiz a Tradição cristã e as verdades da fé nas formas de imagem e comparações. Um método novo na época e de grande atualidade, porque hoje somos muito mais movidos pela imagem da lógica tecnológica do que pela abstração.

O estilo de Cirilo é popular. Ele não se preocupa com um princípio, meio e fim, como era costume na apologética. Sua preocupação era propedêutica, ou seja, preparava o ouvinte para um ensinamento mais completo. Por isso seguia a intuição do auditório para Ihes falar ao coração. Era de fato um comunicador sensível que sabia fazer o jogo das palavras e das contradições a partir da capacidade de compreensão dos ouvintes.

Na primeira catequese depois do batismo, Cirilo usava com os neófitos as imagens contrastantes do Ocidente versus o Oriente, de Moisés e Jesus Cristo. O Oriente simboliza o lugar do nascer do sol, ou seja, Jesus Cristo, enquanto o Ocidente é o lugar das trevas e do pecado. Assim era a fórmula:

Por essa razão, simbolicamente olhais para o Ocidente e renunciais a este príncipe tenebroso e sombrio. O que então cada um de vós, de pé, dizia? Renuncio a ti, satanás, a ti, mau e crudelíssimo tirano: já não temo, dizias, a tua força. Cristo a 
destruiu, fazendo-me partícipe de seu sangue e de sua carne, a fim de abolir a morte pela morte e eu não estar eternamente sujeito à escravidão. Renuncio a ti, serpente astuta e capaz de todo o mal. Renuncio a ti, que, com armas insídias e simulando amizade, praticaste toda sorte de iniquidade e sugeriste a nossos primeiros pais a apostasia. Renuncio a ti, satanás, artífice e cúmplice de todo o mal. ${ }^{14}$

Dessa forma, o cristão recebia o batismo voltado para o Ocidente para renunciar às obras do demônio. A imagem da presença-ausência é contundente. Existe um espaço que divide o que antes era mau e o que agora é santo. Isto se apresenta mais claro na contradição entre as figuras de Moisés e Jesus:

Passai agora comigo das coisas antigas às novas, da figura à realidade. Lá Moisés foi enviado por Deus ao Egito; aqui Cristo, do sei do Pai, foi enviado ao mundo. Aquele para tirar o povo do Egito; Cristo para livrar os que no mundo são acabrunhados pelo pecado. Lá o sangue do cordeiro afastou o anjo exterminador; aqui o sangue do cordeiro Imaculado, Jesus Cristo, constituiu um refúgio contra os demônios. Aquele tirano perseguiu até o mar este povo antigo; e a ti, o demônio atrevido, impudente e príncipe do mal, te segue até as fontes mesmas da salvação. Aquele afogou-se no mar; este desaparece na água da salvação. ${ }^{15}$

Trata-se, então, de uma figura de rompimento entre o que fora revelado no Antigo Testamento e o que agora o cristão vive a partir de Jesus Cristo. Interessante é que toda a simbologia antiga é recuperada em função da pessoa de Jesus, que se torna na leitura ciriliana a verdade constitutiva do ser e do agir cristãos. Sem fazer alusão direta aos conflitos de Niceia e Constantinopla, ele fundamenta as verdades defendidas nos Concílios e coloca o cristão na linha do ensinamento da Igreja, sem causar conflitos doutrinários; simplesmente faz uso de imagens para comunicar uma verdade.

Sem forçar o texto de Cirilo, é possível dizer que ele instaura uma nova racionalidade comunicacional da catequese. Eis exatamente a novidade mistagógica que forma o imaginário religioso do neófito. Se, por um lado, a

14 Ibid., p. 27.

15 lbid., p. 26.

Revista de Cultura Teológica - v. 18 - N. 72 - OUT/DEZ 2010153 
racionalidade patrística era apologética, em Cirilo ela se torna ritual-gesto e contraste. Ou seja, o cristão sente nos ritos e nos gestos o significado de Jesus Cristo como o salvador, pois nele tudo se torna presença visível, mantendo, no entanto, o mistério. Ele concluiu esta catequese com a chamada à vigilância, quer dizer, não retornar às tentações do Ocidente:

Fortalecido por estas palavras, vigiai. Pois nosso adversário, o diabo, como foi lido, anda ao redor, buscando a quem devorar. Deveras, nos tempos anteriores a este, a morte devorava, poderosa. Depois do batismo sagrado da regeneração, Deus enxugou toda lágrima de todas as faces. Com efeito, já não choras por teres te despido do velho homem, mas estás em festa porque te revestiste com a vestimenta da salvação, Jesus Cristo. ${ }^{16}$

$\mathrm{Na}$ segunda catequese, as imagens usadas por Cirilo chamavam a atenção sobre os efeitos que o rito e os gestos do batismo causavam na vida do neófito: despojamento das vestes do velho homem (nudez); a unção (exorcismo); imersão na água (morte e sepultamento); a adoção de filhos pelo Pai. Somente depois de passar pelo rito é que o cristão toma consciência do que aconteceu consigo. Assim como Cristo passou pela morte real, o cristão também passa pela morte separando-se de todas as obras do Ocidente.

A base de argumentação doutrinária de Cirilo é a carta de São Paulo aos Romanos, contudo ele não se detém em citações, mas cria uma imagem do despojamento do velho homem, pois naquele tempo os neófitos eram revestidos com novas roupas para entrarem na piscina que simbolizava 0 túmulo, o sepultamento. A unção era exatamente diante do corpo adormecido para o pecado que, ao ser ungido, ressurgia para a vida nova. Todo esse processo seguia um ato de nascer e morrer que aproximava o neófito às verdadeiras ações de Cristo. E Cirilo pedia insistentemente: "Retende tudo em vossa memória, rogo-vos, para que eu, ainda que indigno, possa dizer-vos: amo-vos porque sempre vos lembrais de mim e conservais as tradições que vos transmiti”. ${ }^{17}$

$\mathrm{Na}$ terceira catequese, Cirilo se remete à crisma:

Batizados em Cristo e dele revestidos, vos tornastes conformes ao Filho de Deus. Em verdade, Deus predestinando-nos

\footnotetext{
16 Ibid., p. 30.

17 Ibid., p. 36.
}

154 Revista de Cultura Teológica - v. 18 - N. 72 - OUt/DEZ 2010 
à adoção de filhos, nos fez conformes ao corpo glorioso de Cristo. Feitos, pois, partícipes de Cristo, não sem razão, sois chamados cristos e é de vós que Deus disse: "Não toqueis os meus cristãos". Ora, vós vos tornastes cristos, recebendo o sinal do Espírito Santo, e tudo se cumpriu em vós em imagem, pois sois imagem de Cristo. ${ }^{18}$

Os cristãos ungidos se tornam cristos, quer dizer, a presença de Cristo ressuscitado. É uma imagem muito forte esta da mistagogia de Cirilo. Repete-se, no entanto, o conceito de Edgar Morin de imagem presença-ausência, pois, mesmo sendo o cristão ungido, Cristo, não deixa de ser uma pessoa imagem, representativa, in persona di Cristo. No entanto, é uma presença inegável, pois a pessoa ungida está na sociedade e age diferentemente da mesma. Temos um testemunho sobre isto cuja data e autor não são consensuais até hoje, trata-se da Carta a Diogneto:

Não se distinguem os cristãos dos demais, nem pela região, nem pela língua, nem pelos costumes. Não habitam cidades à parte, não empregam idioma diverso dos outros, não levam gênero de vida extraordinário. Moram na própria pátria como peregrinos. Casam-se como todos os homens e como todos procriam, mas não rejeitam os filhos. Estão na carne, mas não vivem segundo a carne. Obedecem às leis estabelecidas, todavia, superam-nas pela vida. Amam a todos, e por todos são perseguidos. Pobres, enriquecem a muitos. Amaldiçoados, e bendizem. ${ }^{19}$

O texto de Diogneto afirma ainda que os cristãos são como que "a alma do mundo". Aqui também é forte a ideia de uma presença que ao mesmo tempo se constitui numa ausência expressiva.

A quarta catequese, por sua vez, se debruça sobre o significado do corpo e do sangue de Cristo. O mais impressionante é que Cirilo não fala da expressão Corpo e Sangue como algo meramente simbólico:

18 Ibid., p. 37.

19 A carta a Diogneto, p. 23. Diogneto, um pagão, escreveu um pequeno livro narrando a vida cotidiana dos cristãos. O texto mostra a intrigante vida cristã imersa no contexto pagão, mas com uma mensagem nova não escrita em belas doutrinas e sim na vida. Talvez seja do século II. No entanto, existem controvérsias sobre a origem do texto e sua data, muito embora o conteúdo não perca sua essencialidade. Talvez Cirilo tenha conhecido o texto, porém não se pode comprovar. 
Portanto, com toda a certeza recebemo-los como corpo e sangue de Cristo. Em forma de pão te é dado o copo, e em forma de vinho o sangue, para que te tornes, tomando o corpo e o sangue de Cristo, cocorpóreo e consanguíneo com Cristo. Assim nos tornamos portadores de Cristo (cristóforos), sendo nossos membros penetrados por seu corpo e sangue. Desse modo, como diz o bem-aventurado Pedro, "tornamo-nos partícipes da natureza divina" $(2 \mathrm{Pd} 1,4){ }^{20}$

Ele usa o argumento da mudança do pão em corpo e do vinho em sangue a partir da vida do cristão. Nele se torna o Cristo alimento; então, o cristão é na verdade a presença eucarística que se perpetua no tempo e fora do ambiente sagrado. Por isso, ele insistia muito que não bastava passar pelo rito, mas era necessário tornar-se rito.

O que tudo isso tem a ver com a comunicação? Diria aquilo que Edgar Morin já defendia na sua teoria: o imaginário irrompe no real. ${ }^{21}$ Vivemos sempre no registro da duplicidade, neste caso: real-imaginário, subjugados-libertos, temporais-atemporais, objetivos-subjetivos. Da concepção do que somos chegamos a criar a imagem. Então, o imaginário é salutar e é constitutivo do agir do ser humano. O que Cirilo, no século IV, fez foi exatamente se apropriar das categorias simbólicas da fé para nutrir a experiência vivida pelos neófitos na noite de Páscoa, quando foram batizados. Com isso ele possibilitou que os mesmos tornassem o rito uma realidade sensível e não mero conceito.

A quinta catequese aos neófitos é sobre o rito da Celebração Eucarística. Cirilo recorda o ritual eucarístico como um diálogo entre a assembleia e Deus. Ele fala da pureza como algo que aproxima do divino:

Com o corpo sujo nem sequer teríamos entrado na igreja. Mas lavar as mãos é símbolo de que nos devemos purificar de todos os pecados e de todas as faltas. Já que as mãos são símbolos das obras, lavamo-las, indicando evidentemente a pureza e a irrepreensibilidade das obras. ${ }^{22}$

\footnotetext{
20 SÃO CIRILO DE JERUSALÉM. Catequeses mistagógicas, p. 43.

21 SANTOS, E. R. As teorias da comunicação, da fala à internet, p. 95.

22 SÃO CIRILO DE JERUSALÉM. Catequeses mistagógicas, p. 46.
} 
A essa aproximação segue o símbolo da paz que une os cristãos entre si, é o gesto da reconciliação. Com esses dois gestos, o coração do cristão se eleva a Deus e dá graças e louvores. Somente assim é pedido que o Espírito venha sobre o pão e o sangue para que se torne a presença real do Senhor. A partir desta presença, o ritual recorda os vivos e os mortos que entram em comunhão na Ceia do Senhor. Daí em diante a assembleia se volta para o Pai na oração do Pai-Nosso: santificado seja o teu nome; venha o teu reino; seja feita a tua vontade; nosso pão substancial dá-nos hoje; perdoa-nos as nossas ofensas assim como nós perdoamos; não nos deixes cair em tentação. Na realidade Cirilo demonstra que a santificação de Deus proclamada pela assembleia é a santificação do humano.

Não há real mediação entre Deus e os seres humanos a não ser pela santificação, que é uma dimensão futura. Quando pedimos o pão de cada dia, não é tanto a matéria, mas o alimento que sacia a fome do ser humano de sentir a providência de Deus. $O$ pão também transparece a bondade de Deus que perdoa os pecados de todos os que se alimentam dele. À medida que nos alimentamos do Pão do céu, nos perdoamos e criamos uma ciranda de misericórdia.

Quando recebem a comunhão, as mãos do cristão se tornam o altar de Deus:

Ao te aproximares da comunhão, não vás com as palmas das mãos estendidas, nem com os dedos separados; mas faze com a mão esquerda um trono para a direita como quem deve receber um Rei e no côncavo da mão espalmada recebe o corpo de Cristo. ${ }^{23}$

Interessante que na atualidade a comunhão é feita exatamente assim, mesmo que haja liberdade para receber a comunhão de outras formas. Cirilo, mesmo antes do período jansenista, ${ }^{24}$ trabalha a superação de qualquer

23 Ibid., p. 54.

${ }^{24} \mathrm{O}$ jansenismo foi um movimento religioso, também de cunho político, desenvolvido na França e na Bélgica, nos séculos XVII e XVIII. O bispo católico de Yprès, Jansênio, criou uma versão do Calvinismo, seguimento protestante, baseado na polêmica de Santo Agostinho contra os pelagianos. Evidentemente uma leitura errônea da teologia agostiniana, pois Jansênio defendia como elemento central da sua doutrina uma visão pessimista do ser humano corrompido pelo pecado original, incapaz de obra boa, portanto, privado da graça de Deus. O ser humano já nascia predestinado ao céu ou ao inferno e não podia mudar tal destino. Deus seria um juiz cruel e justo, pois só concederia a graça a quem 
distanciamento entre imagem e símbolo. Na verdade, a prática da comunhão se imbui de uma realidade palpável, alimento, e não mera representação, movida pelo medo e pecado.

O conteúdo, portanto, das cinco catequeses cirilianas nos introduzem assim em uma realidade imagética que não separa o símbolo dos ritos e gestos. Há uma simbiose que se instaura no agir do cristão tornando-o presença sacramento visível de Deus. Esta realidade instaura o imaginário religioso porque se baseia numa experiência religiosa vivida nos ritos e compreendida na prática ordinária e piedosa do fiel.

Em seguida vamos refletir sobre o valor da palavra nesta mistagogia, pois ela é o gancho para a explicação dos ritos e gestos, mas sempre figura que aponta para o passado, vivida na realidade presente em função da construção futura - escatologia: "Todas as vezes que comemos deste pão e bebemos deste cálice, anunciamos, Senhor, a vossa morte enquanto esperamos a vossa vinda" (1 Cor 11,26).

\section{A QUESTÃO DA PALAVRA MISTAGÓGICA NAS CATEQUESES DE SÃO CIRILO DE JERUSALÉM}

A arte cênica (cena) é muito importante no ato de comunicar. Isto é constatável na obra de Cirilo. Genésio Severino, num pequeno livro sobre comunicação, nos diz a respeito que "o cenário (o ground) tem muito mais força do que qualquer outra forma de comunicação". ${ }^{25}$ Isto significa que todo o ambiente é importante para produzir o efeito que se quer no receptor. Nesse sentido, Cirilo foi genial porque utilizou tanto do espaço sagrado das Igrejas como dos objetos religiosos para introduzir o ouvinte no Mistério.

A palavra, por conseguinte, na obra de Cirilo, mais que verbalização, é cênica. A forma como ele preparava o espaço e mostrava o sentido de cada ação conscientizava o neófito de sua nova vida em Jesus Cristo. Então, toda

ele quisesse; quem não recebesse ficaria à mercê da condenação eterna. No fundo, o jansenismo defendia que a pessoa não tinha livre arbítrio; estava destinada a cumprir seu destino traçado por Deus desde a criação. Os jansenistas eram contrários à comunhão frequente porque exigiam a perfeição e aconselhavam a "comunhão espiritual", uma vez que poucos tinham recebido o mérito de receber o corpo e o sangue de Jesus Cristo. Também atacavam o papa e queriam a independência com relação à Igreja de Roma.

25 SILVA FILHO, G. Z. Comunicação e pastoral; como melhorar a comunicação nas ações e eventos pastorais. São Paulo: Editora Salesiana, 2001, p. 49. 
a simbologia presente na comunicação de Cirilo estabelecia relações com o mundo religioso, com a própria pessoa e com o transcendente. ${ }^{26}$ Dessa simbologia nasceu uma linguagem capaz de expressar o pensamento da pessoa que "liga o homem ao outro homem no que de mais humano cada um possui". ${ }^{27}$

Essa expressão simbólica oculta um sentido invisível que chamo de imaginário religioso, pois a linguagem vai além do que revela. Por isso Cirilo usava genialmente os objetos religiosos como forma de linguagem para a compreensão do Mistério celebrado na noite da Vigília de Páscoa.

Tendo presente esta realidade, precisamos conceituar a linguagem simbólica em duas vertentes: linguagem denotativa e conotativa. A linguagem denotativa, neste caso a Palavra, é sempre signo, contém um significado aceito pelo grupo e pela cultura, por exemplo: o fogo, a cruz, o altar. $\mathrm{O}$ neófito facilmente compreendia esta linguagem apenas ao ver os signos. A linguagem conotativa é aquela capaz de gerar associações, conceitos, emoções e ações, explica sempre algo indizível. ${ }^{28}$

Aqui, portanto, desejo trabalhar esta Palavra mistagógica que se revela em signo e conceitos, formando assim um quadro imaginário profundamente religioso cristão. Trata-se de uma cultura imagética que cria relações. ${ }^{29}$

\subsection{A palavra construída aos iluminados (catecúmenos)}

A cultura Oriental de Cirilo é menos analítica e conceitual; trata-se de "uma cultura de informações paralelas, justapondo fatos, notícias particulares, fragmentos da realidade". ${ }^{30}$ Evidentemente que na base desta forma de comunicação existe uma lógica que não reproduz o esquema mental em tempo real, mas na relação entre as imagens. Era, podemos dizer assim, uma construção imagética da palavra em pleno século IV. O que

\footnotetext{
26 NASSER, M. C. Q. C. O que dizem os símbolos, p. 7.

27 Ibid., p. 8.

28 Ibid., pp. 8-9.

29 Por cultura imagética entendemos aquela que nasce justaposta uma ao lado da outra longe da construção verbal racional herança da filosofia grego-latina. O neófito, neste caso, não precisava de textos, mas das várias composições de imagens que se agrupavam no espaço das igrejas. A estruturação destas imagens com as catequeses de Cirilo formava o conteúdo. É a lógica da geração das novas tecnologias.

30 SILVA FILHO, G. Z. Comunicação e pastoral, p. 33.
} 
hoje constatamos como realidade na maneira como as novas gerações se relacionam com a cultura da imagem, Cirilo soube efetivar no seu contexto para formar os neófitos na compreensão da nova identidade assumida à luz do ressuscitado: Jesus Cristo.

O grande modelo desta forma de linguagem aparece na forma transcendental do Templo na cultura judaica e, consequentemente, cristã. Diz Mircea Eliade:

A basílica cristã, e mais tarde a catedral, retoma e prolonga 0 simbolismo da Jerusalém celeste e do Paraíso. Por um lado, a igreja é concebida como imitação da Jerusalém celeste, e isto desde a antiguidade cristã; por outro lado, reproduz igualmente o Paraíso ou o mundo celeste. Mas a estrutura cosmológica do edifício sagrado persiste ainda na consciência da cristandade: é evidente, por exemplo, na igreja bizantina. As quatro partes do interior da igreja simbolizam as quatro direções do mundo. O interior da igreja é o Universo. O altar é o Paraíso. A porta imperial do altar denomina-se também porta do Paraíso. $O$ meio do edifício da igreja representa a Terra. As quatro partes do interior da igreja simbolizam as quatro direções do mundo. ${ }^{31}$

Essa forma simbólica de conceber o espaço sagrado não considera o Templo como um objeto para habitar, mas o Universo. Toda construção sagrada significa um novo começo da criação. ${ }^{32}$ Essa constatação de um estudioso das religiões reafirma nossa tese de que, ao escolher a igreja do Santo Sepulcro para suas catequeses, Cirilo outra coisa não faz que colocar os neófitos dentro de um Universo, cujo centro unificador é o ressuscitado, alfa e ômega, princípio e fim da história. Do ponto de vista da comunicação, essa linguagem ciriliana tem uma atualidade enorme porque revela sua grande vivacidade e criatividade em construir com os signos a mensagem salvífica que deseja transmitir.

Dessa forma, a catequese ciriliana, realizada dentro do Templo, tinha a capacidade de envolver o ouvinte porque mexia, sobretudo, com dois sentidos: a visão e a audição. Pierre Babin define esta forma de comunicação como modulação, quer dizer, "um conjunto de vibrações dotadas de

31 ELIADE, M. O sagrado e o profano: a essência das religiões, pp. 57-58.

32 Ibid., p. 54. 
intensidades e de alturas diversas, de ritmos e de harmonia particulares" ${ }^{33}$ Um meio de comunicação com muita força de modulação é o rádio. Ele envolve as pessoas, leva até a comunicação, faz emergir no imaginário a forma do fato. É possível, então, caracterizar a construção da palavra nas catequeses de Cirilo em três formas:

1. Capacidade de escuta: os neófitos permaneciam tão sintonizados com as imagens, os sons, as cores, os objetos e as palavras que aprendiam a ouvir, mesmo sem a voz do catequista.

2. Estar juntos: o grupo de neófitos formava uma harmonia comunitária tão estreita e forte, que envolvia a todos na participação e construção coletiva da mensagem. Talvez por isso, julgo eu, Cirilo não permitia que as catequeses fossem inscritas e comunicadas. Era necessário estar juntos para compreender o significado das palavras.

3. Comunicar o essencial: nesta forma modular de comunicação, o catequista Cirilo conseguia atingir o instinto do grupo, a visão de mundo e a moção do Espírito Santo em suas vidas.

Nesse processo dinâmico era construída a palavra nas catequeses de Cirilo dentro de um sistema modular, exatamente como hoje os interlocutores conseguem interagir com as mídias.

\subsection{A palavra que constrói o significado imaginário do divino e do humano aos neófitos}

Como acabamos de analisar, as catequeses cirilianas se constituíram em códigos através dos aspectos cênicos e da Palavra. Do ponto de vista cênico, o grande palco era o Templo, como um ícone simbólico da realidade almejada, ou seja, a experiência pascal de Jesus Cristo que se constituía na própria vida do neófito. Três eram os elementos que constituíam este espaço: o altar, a pia batismal e a cruz. O altar remetia à ideia de Paraíso, mas também de sacrifício, portanto, ícone do Senhor morto que se torna oferta e oferente ao Pai. A pia batismal representava o lugar da morte pelo banho nas águas, da qual ressurgia o novo homem e mulher, transfigurados no ressuscitado. A cruz expressava a vitória da vida sobre o peso da morte.

33 BABIN, P. A era da comunicação, p. 15. 
Todo este espaço simbólico, e o Templo como um todo, criava a imagem da "casa" que acolhia o neófito no seio da Igreja.

$\mathrm{Na}$ verdade, o aspecto cênico substituía a realidade invisível, exatamente como escreve São João: "O que era desde o princípio, o que ouvimos, o que vimos com os nossos olhos, o que contemplamos e o que as nossas mãos apalparam da vida [...] tornou-se visível para nós" (1Jo 1,1-2). Quando escreveu isso, o autor não se referia a algo que estava ali ao alcance dos seus interlocutores, mas sim a algo que de fato existiu e que, agora, se torna signo. Então, a palavra construída é mediadora porque o signo na sua realidade palpável, segundo João, é sempre interface porque abre possibilidades e ao mesmo tempo fecha. A interface é como nossa pele. Ela faz a mediação entre as articulações, gorduras, veias e ossos, mas esconde o que está por baixo. Por isso, considero as catequeses como comunicação cênica, pois a palavra se constrói num emaranhado de ritos que, ao mesmo tempo em que introduzem o neófito na nova realidade do mistério da fé, outrora visível, escondem a pessoa do ressuscitado.

Então, a mistagogia na forma de comunicar de Cirilo só pode ser decodificada pelo neófito na sua inserção na sociedade. Daí o grande esforço do mistagogo em preservar seus escritos e suas catequeses da especulação porque a experiência do Senhor não se dá na matéria, mas na não materialidade, preenchendo o vazio da nossa ritualidade que, sem decodificação, permanece incompreensível e efêmera.

Naquele contexto de disputas ideológicas religiosas do século IV, como analisamos no primeiro tópico, que mergulhou em conceitos filosóficos na tentativa de materializar o mistério, Cirilo manteve-se na "corda bamba" cênica, sem, contudo, perder uma lógica interpretativa do ato de fé, sempre no arco simbólico e gestual do mistério pascal que, mesmo sendo representado em seus ritos, permanece inesgotavelmente mistério.

\subsection{Os gestos que tornam visível o imaginário das palavras}

Entramos aqui num discurso complexo. Há uma ciência que estuda a imagem, chama-se eicônica. ${ }^{34}$ Toda imagem, desde pinturas, estampas de selos, artificiais ou não, representa uma linguagem verbal ou mental. Isto

34 SANTAELLA, L.; NOTH, W. Imagem: cognição, semiótica, mídia, p. 33. 
para dizer que nas catequeses de Cirilo os gestos são imagens que formam um discurso eicônico que dão forma a um grande painel da vida cristã no cotidiano. Estes gestos - unções, bênçãos, mergulho na água, os ritos que marcavam a passagem de uma fase a outra das catequeses com a entrega do Pai Nosso, do creio, da cruz - eram signos plásticos, ${ }^{35}$ porque se tornavam semelhantes mesmo sendo representativos de momentos específicos. Não tinha o mesmo significado receber, por exemplo, o Pai-Nosso (não material) e uma cruz (material). Entretanto, eles eram imagens de uma única realidade: O Senhor ressuscitado, cuja expressão visível era o neófito.

Por conseguinte, os gestos que Cirilo sabiamente usava carregados de simbologia formavam uma linguagem que revelava o sentido da imagem construída no imaginário do neófito. Ao receber esses gestos, o neófito era revestido dos signos fundamentais da fé que davam novo sentido à vida, homem e a mulher novos, por tanto ressuscitados; no dizer de Jesus: "Se alguém não nascer do alto, não poderá ver o Reino de Deus" (Jo 3,3). Neste sentido, o batismo era muito mais expressivo como experiência da morte com o mergulho na água e a unção, do que como a simples purificação ou perdão dos pecados, conforme acontece em nossos dias. Assim se referia Cirilo a essa experiência:

Logo que entrastes, despistes a túnica. E isto era imagem do despojamento do velho homem com suas obras (Col 3,9). Despidos, estáveis nus, imitando também nisso o Cristo nu sobre a cruz. Por sua nudez despojou os principados e as potestades e no lenho triunfou corajosamente sobre eles. As forças inimigas habitavam em vossos membros. Agora já não vos é permitido trazer aquela velha túnica, digo, não esta túnica visível, mas o homem velho corrompido pelas concupiscências falazes (Ef 4,22). Em verdade éreis imagem do primeiro homem, Adão, que no Paraíso andava nu e não se envergonhava $(G n 2,25) \cdot{ }^{36}$

$O$ fato de o neófito depois do batismo ser introduzido no significado dos gestos que fez inaugura em Cirilo uma catequese memorativa, quer dizer, ele passa a falar do passado que se vive no hoje a partir da simbologia representada no batismo. O despojamento da velha túnica, quer dizer, das

${ }^{35}$ O signo plástico tem expressão e conteúdo próprio que cada observador une à sua vivência (cf. ibid., p. 38).

36 SÃO CIRILO DE JERUSALÉM. Catequeses mistagógicas, pp. 32-33. 
obras anteriores ao conhecimento de Jesus Cristo, para assumir a nova túnica, ou seja, o revestimento da pessoa do ressuscitado é uma linguagem não apenas racional, mas conotativa, pois une o símbolo ao gesto.

O imaginário religioso construído de forma eicônica na linguagem no século IV causa uma grande estranheza e perplexidade porque os instrumentos de que Cirilo dispunha eram palpáveis, porém descodificavam uma realidade transcendental. Isto é muito interessante do ponto de vista do imaginário religioso. O nome já está dizendo: "imaginário". Quer dizer, algo que não é perceptível pela pura materialidade, mas pela palavra-imagem em toda a sua modulação. É ilustrativo o que dizia Cirilo aos neófitos sobre o significado do mergulho na piscina:

Imersos três vezes na água e em seguida emergidos, significando também com isto, simbolicamente, o sepultamento de três dias de Cristo, do mesmo modo vós, com a primeira imersão, imitastes o primeiro dia de Cristo na terra, e, com a imersão, a noite. Como aquele que está no dia tudo enxerga na luz, assim vós na imersão, como na noite, nada enxergastes, mas na emersão, de novo vos encontrastes no dia. E no mesmo momento morrestes e nascestes. Esta água salutar tanto foi vosso sepulcro como vossa mãe. ${ }^{37}$

Certamente o neófito, ao ouvir estas palavras, compreendia não apenas o rito, mas o seu significado simbólico a partir de sua nova condição de ressurgido para a vida nova. Como veremos mais adiante a ritualidade da morte marca profundamente a experiência religiosa.

\subsection{A passagem do rito ao mistério: o imaginário religioso}

$\mathrm{Na}$ vida de toda pessoa, um ritual de passagem marca o fim de uma fase e o começo de outra totalmente distinta, mas em continuidade com a anterior (por exemplo, da infância para a puberdade). No homem religioso isto é fundamental. ${ }^{38}$ No caso dos ritos iniciáticos há uma "mudança do regime ontológico do neófito". ${ }^{39} \mathrm{O}$ rito marcava a morte desta vida profana para a

\footnotetext{
3 Ibid., p. 34.

38 ELIADE, M. O sagrado e o profano: a essência das religiões, p. 150.

39 Ibid., p. 152.
}

164 ReVISTA de Cultura TeOlógica - v. 18 - N. 72 - OUt/DEZ 2010 
nova vida em Cristo, sagrada. Era todo esforço por atingir a um ideal de humanidade, como bem nos diz Mircea Eliade:

O neófito morre para sua vida infantil, profana, não regenerada, renascendo para uma nova existência, santificada, ele renasce também para um modo de ser que torna possível o conhecimento, a ciência (grifo do autor). O iniciado não é apenas um "recém-nascido" ou um "ressuscitado": é um homem que sabe, que conhece os mistérios, que teve revelações de ordem metafísica. Durante seu treinamento na selva, aprende os segredos sagrados. ${ }^{40}$

Por conseguinte, nas catequeses cirilianas, verdadeiras narrativas sagradas, formava-se a base de todo o imaginário religioso. ${ }^{41}$ São, portanto, epocais, porque suas categorias são absorvidas em categorias míticas e utópicas. Por isso, ao entrar no campo das imagens, o estudo do imaginário religioso torna-se muito complexo. Amauri e Yonne, a respeito, dizem:

Torna-se complexo, para a maioria dos estudiosos, investigar o imaginário como objeto de pesquisa devido à constituição de elementos-imagens que organizam um dever-ser-para o sujeito. Quando se tematiza o imaginário, quase sempre se projetam dimensões políticas, econômicas e sociais. A existência de imagens construídas pelo sujeito representa lugares de memória, tecendo uma história de seu existir naquele momento. Em sua origem, o imaginário configura uma imagem ou realidade secundária, torna-se semelhante ao que apreende, uma aparência constituída pela reflexão do homem. O imaginário é, nesse sentido, uma representação das coisas que existem no mundo. ${ }^{42}$

Como estamos dentro do campo da comunicação, este conceito nos ajuda a entender que o imaginário religioso que aos poucos se forma na identidade do neófito compreendia tanto os lugares de memória, pois as catequeses mistagógicas aconteciam no interior da igreja e na sua linguagem eicônica, como também as formas narrativas sagradas que os símbolos ali

40 ELIADE, M. O sagrado e o profano: a essência das religiões, cit., p. 153.

41 FERREIRA, C. A.; GROSSI, Y. S. O imaginário religioso na construção de subjetividade nômades: o fenômeno da migração religiosa. In: www.abhr.otg.br/wp-content/uploads/2008/12/ yonne-e-amauri.pdf.

42 Ibid., p. 3. 
presentes personificavam. Eram, na verdade, imagens reais de uma experiência religiosa.

Assim sendo, a linguagem comunicacional de Cirilo fazia referência, sem sombra de duvida, às categorias míticas e utópicas. Enquanto míticas, a linguagem modular usada descrevia a origem da religião cristã com seus fenômenos essenciais: a morte e a ressurreição de Jesus Cristo. Consequentemente, conduzia o neófito aos aspectos utópicos da religião, concretamente, sua migração do paganismo ou judaísmo para o cristianismo, criando os aspectos subjetivos do ato de fé, porque expressavam o desejo na realidade transcendental do símbolo. ${ }^{43}$ Exatamente porque, no dizer de nossos autores, "a utopia religiosa permite a compreensão da relação com o passado mítico e a esperança de uma vida futura". ${ }^{44}$ Portanto, o estudo do imaginário religioso compreende o valor das imagens dentro do círculo religioso.

Permitindo a passagem do rito do batismo na noite da Páscoa para o imaginário religioso, as catequeses de Cirilo constituíam para os neófitos uma construção consciente dos elementos fundamentais da religião como seus dogmas e sua concepção de mundo. ${ }^{45}$ Este é, por conseguinte, o campo do mistério no cenário religioso. Entenda-se por mistério não aquilo que não se entende, mas o que transcende ao material. Ora, o neófito migrava de uma religião a outra, através desses valores míticos e utópicos, que constituíam seu novo horizonte imagético. Daí a metamorfose na sua identidade que legitimava uma nova pertença no seio da Igreja e a inserção no mundo. ${ }^{46}$ Um breve relato da catequese sobre a Eucaristia pode ilustrar esta nova realidade do cristão:

Todavia, agora, tendo despido as velhas vestes e revestido espiritualmente a veste branca, é necessário estar sempre vestido de branco. Não dizemos isso absolutamente porque é preciso estar trajado de branco, mas porque deves, em realidade, revestir a veste branca, brilhante e espiritual, a fim de dizeres com o bem-aventurado Isaías: "Com grande alegria me rejubilei

\footnotetext{
43 Ibid., pp. 3-4.

44 lbid., p. 4.

45 Ibid., p. 4.

46 FERREIRA, C. A.; GROSSI, Y. S. O imaginário religioso na construção de subjetividade nômades: o fenômeno da migração religiosa, p. 6.
} 
no Senhor, porque me fez revestir a vestimenta da salvação e me cobriu com a túnica da alegria" (Is 61,10$){ }^{47}$

A carga simbólica do rito é impressionante neste texto Ciriliano. Ele chama o neófito a se tornar eucarístico, ou seja, a ser uma hóstia, branca e brilhante, num mundo sem luz e de fome. Ser Eucaristia no mundo é prolongar na história a mesa partilhada e o altar do sacrifício, no qual Jesus mesmo se faz oferente e oferta. $\mathrm{O}$ cristão é, exatamente, esta nova realidade.

Então, o imaginário religioso possibilitava o encontro saudável de culturas diferentes e fortalecia os laços de pertença à nova realidade eclesial. Consciente ou não, as catequeses cirilianas faziam o processo de inculturação do neófito dentro da Igreja neste trânsito subjetivo nômade das imagens, em suas categorias míticas e utópicas. Essa passagem produzia uma ruptura com o passado e gerava uma fundação do mundo. ${ }^{48}$ À medida que Cirilo introduzia os neófitos na Igreja, ele abria um portal novo de comunicação com o sagrado, no qual, segundo Mircea Eliade, "o mundo profano é transcendido [...]. O templo constitui, por assim dizer, uma 'abertura' para o alto e assegura a comunicação com o mundo dos deuses". ${ }^{49}$ Ora, nas catequeses de Cirilo, o Templo era o lugar privilegiado de comunicação com o sagrado:

Todo espaço sagrado implica uma hierofania, uma irrupção do sagrado que tem como resultado destacar um território do meio cósmico que o envolve e o torna qualitativamente diferente. Quando, em Haran, Jacó viu em sonhos a escada que tocava os céus e pela qual os anjos subiam e desciam, e ouviu o Senhor, que dizia, no cimo: "Eu sou o Eterno, o Deus de Abraão!", acordou tomado de temor e gritou: "Quão terrível é este lugar! Em verdade é aqui a casa de Deus: é aqui a Porta dos Céus" (Gn 28,12-19). ${ }^{50}$

A imagem que transcende o espaço "Porta dos Céus" é a modulação do santuário entre o céu e a terra. Nesse sentido, o imaginário religioso é o teofânico, porque manifesta algo desejado pelo neófito, ao mesmo tempo

47 SÃO CIRILO DE JERUSALÉM. Catequeses mistagógicas, p. 45.

48 Isso significa que a redescoberta de um novo centro da existência gera o absoluto para o neófito. É um ponto fixo, "Centro do mundo", neste caso, a pessoa de Jesus Cristo (cf. ELIADE, M. O sagrado e o profano: a essência das religiões, p. 25.

49 Ibid., pp. 29-30.

50 Ibid., p. 30. 
em que o insere na realidade civil e eclesial. Daí a grande importância que dava Cirilo à vivência humana e espiritual do cristão como transformação e irrupção da vida nova em Cristo. O sagrado que passa pelo imaginário religioso tem força de vida e fecundidade: ${ }^{51}$

O desejo do homem religioso de viver no sagrado equivale, de fato, ao seu desejo de se situar na realidade objetiva, de não se deixar paralisar pela relatividade sem fim das experiências puramente subjetivas, de viver num mundo real e diferente - e não numa ilusão. ${ }^{52}$

A construção do imaginário se dá no simbolismo da morte; aliás, todo rito de passagem se caracteriza pela relevância da morte como princípio de um novo começo. É a separação da condição profana, pagã, para a condição de cristão. O próprio batismo, com o mergulho na água, significava o entrar na sepultura, da qual, se saía ressuscitado:

O mistério da iniciação revela pouco a pouco ao neófito as verdadeiras dimensões da existência: ao introduzi-lo no sagrado, a iniciação o obriga a assumir a responsabilidade de homem. É importante ter este fato em mente: o acesso à espiritualidade traduz-se, em todas as sociedades arcaicas, em um simbolismo da morte e de um novo nascimento. ${ }^{53}$

É nesta riqueza simbólica religiosa que o imaginário religioso se constitui como experiência de vida. O neófito, ao continuar o processo iniciático após o batismo na Vigília de Páscoa, entra numa nova dimensão de vida, revestido com os símbolos cristãos. Ele é outro Cristo. Evidentemente, não se esgota nele o mistério desejado, mas começa desde aí a transparecer no seu modo de viver no mundo. A palavra que Cirilo queria construir não era tanto um discurso gramaticalmente correto, mas mais um mártir do cotidiano que, vivificado em Cristo pelo batismo, crisma e Eucaristia, se torna uma luz em meio às trevas. Parece-me que esta era a palavra construída por Cirilo no imaginário religioso cristão do século IV.

Em resumo, podemos dizer que a linguagem denotativa e conotativa aqui se entrelaçam. O signo, linguagem denotativa, gera o imaginário religioso na

\footnotetext{
51 lbid., p. 31.

52 lbid., p. 32.

53 ELIADE, M. O sagrado e o profano: a essência das religiões, p. 156.
} 
migração do homem pagão para o homem religioso, com toda a exuberante expressão do Templo, que liga o céu e a terra. Já a linguagem conotativa exerce uma força de conexão entre as palavras, criando a experiência religiosa fundamentada nos ritos de passagem. $O$ veículo que conduz todo o processo é a modulação, pois, na construção da palavra mistagógica, a audição e a visão exercem um papel fundamental para a ressignificação da comunicação.

\section{REFERÊNCIAS BIBLIOGRÁFICAS}

BARONTO, E. L. A metodologia litúrgico-catequética do batismo nas catequeses mistagógicas de Cirilo de Jerusalém. In: Revista de Catequese. São Paulo, n. 82, pp. 53-55, 1998.

BENTO XVI, São Cirilo de Jerusalém. In: L'osservatore Romano. Vaticano: $\mathrm{n}$. 26, 30 junho, p. 12, 2007 (catequese do Papa).

BABIN, P. A era da comunicação. São Paulo: Paulinas, 1989.

CALOGERO, R. Lo sfondo esegetico della catechesi palestinense in Epifanio di Salamina e in Cirillo di Gerusalemme. In: Biblioteca religiose - 106 Esegesi e catechesi nei Padri (século II-IV) a cura di Sergio Felici. Roma: LAS, 1993.

ELIADE, M. O sagrado e o profano: a essência das religiões. São Paulo: Martins Fontes, 2001, $5^{\mathrm{a}}$ ed.

ELORRIAGA, C. San Cirilo de Jerusalén, catequesis. Bilbao: Desclée de Brower, 1991.

FERREIRA, A.; GROSSI, Y. S. O imaginário religioso na construção de subjetividade nômades: o fenômeno da migração religiosa. Disponível em: www.abhr. otg.br/wp-content/uploads/2008/12/yonne-e-amauri.pdf. Acesso em: 10/02/2010.

HAMMAN, A. Os padres da Igreja. São Paulo: Paulinas, 1980.

JERUSALÉM, São Cirilo. Catequeses mistagógicas. Tradução de Frederico Vier. Introdução e notas de Frei Fernando Figueiredo. Petrópolis/RJ: Vozes, 2004, $2^{\mathrm{a}}$ ed.

LELO, F. A. Catequese com estilo catecumenal. São Paulo: Paulinas, 2008.

MONDONI, D. História da Igreja na Antiguidade. São Paulo: Loyola, 2001.

NASSER, M. Q. C. O que dizem os símbolos? São Paulo: Paulus, 2003.

SANTANELA, L.; NOTH, W. Imagem: cognição, semiótica, mídia. São Paulo: lluminaras Ltda, 2005, $4^{\text {a }}$ ed.

SANTOS, E. R. As teorias da comunicação, da fala à internet. São Paulo: Paulinas, 2003.

SILVA FILHO, G. Z. Comunicação e pastoral: como melhorar a comunicação nas ações e eventos pastorais. São Paulo: Salesiana, 2001. 